\title{
Effectivness of Creative Thinking Module on Figural Creativity of Engineering Undergraduate in Malaysia
}

\author{
Chua Yaw Long ${ }^{1,2}$, Balamuralithara Balakrishnan ${ }^{2}$, Choong Pooi Ying ${ }^{1} \&$ Koh Yit Yan ${ }^{3}$ \\ ${ }^{1}$ Universiti Tenaga Nasional, Jalan Ikram-Uniten, 43000 Kajang, Selangor, Malaysia \\ ${ }^{2}$ Fakulti Seni, Komputeran dan Industri Kreatif, Universiti Pendidikan Sultan Idris, 35900 Tanjong Malim, Perak \\ Darul Ridzuan, Malaysia \\ ${ }^{3}$ Faculty of Engineering and Built Environment, University of Newcastle, 6 Temasek Boulevard, \#10-02/03, Suntec \\ Tower 4, Singapore 038986 \\ Correspondence: Balamuralithara Balakrishnan, Fakulti Seni, Komputeran dan Industri Kreatif, Universiti \\ Pendidikan Sultan Idris, 35900 Tanjong Malim, Perak Darul Ridzuan, Malaysia. E-mail: balab @ fskik.upsi.edu.my
}

Received: April 27, 2020

Accepted: June 19, 2020

Online Published: June 25, 2020

doi:10.5430/ijhe.v9n4p233

URL: https://doi.org/10.5430/ijhe.v9n4p233

\begin{abstract}
This research paper presents the outcome of research conducted to improve and enhance the creativity level of engineering undergraduates at a private institution of higher learning in Malaysia. A Creative Thinking Module that features six proposed creative thinking tools was developed and administered to a group of 3rd Year Mechanical Engineering Undergraduates in the studied university. The Torrance Test of Creative Thinking Figural Forms were applied to measure the creativity level of respondents in this research. The effects of the Creative Thinking Skills Module developed is obtained through Pre-Test and Post-Test research method, Paired Sample T-Test and Wilcoxon Signed-Rank test are used to analyse the scores, and results indicated the module developed has significantly improved the creativity of the undergraduates.
\end{abstract}

Keywords: creativity, Torrance Test of Creative Thinking, engineering design, paired sample T-Test

\section{Introduction}

Creativity, is it a skill engineers require for the $21^{\text {st }}$ century? The answer is yes according to the Malaysian Engineering Accreditation Council (EAC) Manual. The definition of engineering is the creative application of scientific principles to design or develop structures, machines, apparatus, or manufacturing processes, or works utilizing them singly or in combination; or to construct or operate the same with full cognizance of their design, or to forecast their behaviour under specific operating conditions; all as respects an intended function, economics of operation or safety to life and property (Engineering Accreditation Council, 2017).

It undeniable that, without creativity in engineering, there would not be any engineering solutions to overcome various issues faced by humanity. There would not be any unique solution such as the Falkirk Wheel, which is a unique, rotating boat lift that connects two canals of different elevation to reduce transportation time in Scotland. There would not be innovative patient-ventilator made from scuba mask by various engineering teams around the world to facilitate with the global shortage of medical equipment during the Covid-19 pandemic. Modern-day problems require modern-day solutions as solutions for the problems faces in yesteryears might have been obsoleted due to the ever-changing factors such as socio-economic progression over time. Thus, engineers are required to generate creative solutions to overcome these complicated problems of modern-day (Cropley, 2015).

Engineers are required to work individually or in teams to respond, justify and solve problems individually or in a team (Liu \& Schönwetter, 2004). Problem-solving requires creativity and, fortunately, researchers have deduced that it is possible to teach creativity and creativity could be learnt at the control of individuals (Hewett, 2005). Even way back in the year 2002, research had come out with a conclusion to urge universities to provide avenues for engineering students to nurture creativity (Baillie, 2002). Unfortunately, the initiative to support and cultivate creativity among students has not been sufficient in the educational institutions globally (Brand, Hendy, \& Harrison, 2015; Robinson, 2013; Terkowsky \& Haertel, 2013; Haertel, Terkowsky, \& Jahnke, 2012; Daud, Omar, Turiman, \& Osman, 2012; Beghetto, 2010; Kazerounian \& Foley, 2007). 
Looking back at the current situation of Malaysia, research has concluded that Malaysian engineering graduates lack vital skills to cope with modern-day work demands such as communication skills, presentation skills, creative thinking and innovation (Soon \& Quek, 2013). Malaysia is lacking engineering education curriculums which strikes a balance between engineering technical knowledge and practical modern-day skills such as creativity to equip future engineers with skillsets to ensure they are relevant and remain competitive in this era of globalisation, ensuring Malaysia can remain competitive amidst tough economic times and globalisation (Grapragasem, Krishnan, \& Mansor, 2014). Therefore, it is of vital importance to develop a module that emphasizes on the importance of creative thinking for engineering education. This research tries to reduce this lack of creativity of engineering undergraduate by introducing a creative thinking skill module, thus the need to look into the effectiveness of this module.

\section{Literature Review}

\subsection{Definition of Creativity}

In the past, creativity was believed to be a skill blessed by divine beings to only the privileged. Similarly, creativity was thought to be a form of novel thinking, where problems get reassessed, knowledge gaps being identified, leading towards the emergence of new ideas, then generated ideas are analysed, and lastly logical risks in idea generation are taken after weighing out the consequences. The essential characteristics of creative thinking are widely accepted by researchers as the ability for a person to merge and link ideas in new ways that are novel and useful (Daly, Mosyjowski, \& Seifert, 2014). Rhodes (1961), segregated different characteristics of creativity categories into the 4Ps, representing Process, Person, Press, and Product. For this research project, it will involve the first category only namely the Process. Torrance (1974) extended Rhodes (1961) work further on separately on creativity in the realm of Process and came up with his version of creativity in the Process category.

Creativity as defined by Torrance (1974), a prominent researcher in the subject of creativity as:

"A process of becoming sensitive to problems, deficiencies, gaps in knowledge, missing elements, disharmonies, and so on; identifying the difficult; searching for solutions, making guesses or formulating hypotheses about the deficiencies; testing and retesting these hypotheses and possibly modifying and retesting them, and finally communicating the results."

Creative individuals and non-creative individuals are different in various aspects, predominantly in personalities. Cropley (2001) suggested that creative individuals do not conform to norms, Amabile (1989) indicated that they are risk-takers. Research also shown creative individuals acquire satisfaction when they are engaged in discovering and innovating (Claxton, Edwards, \& Scale-Constantinou, 2006).

\subsection{Measuring Creativity: Torrance Test of Creative Thinking (TTCT)}

Prominent creative researcher and pioneer in creative education, Torrance, developed the well-known TTCT. Various creative researches involving individuals and groups of people of all ages apply TTCT to evaluate attributes in creativity and this test is highly recommended in the field of education (Kim, 2006). TTCT is a compilation of standardized tests that provides reliable measurements on the creativity of subjected participants and is available in various languages.

There are two versions of TTCT namely the Figural test and Verbal test in which both versions have 2 corresponding forms namely Form A and B which can be used interchangeably for pre and post-test (Scholastic, 2018). Throughout the years, TTCT has been relevant and popular among creative researchers as the implementation and scoring system of TTCT has been polished in the year 1974, 1984, 1990 and 1998 (Kim, 2006). TTCT highlights on the measuring of Fluency, Originality, Elaboration and Flexibility as attributes in creativity, but the flexibility attribute was substituted with Abstractness of Titles and Premature Closure following the advancement of TTCT involving figural drawing. (Scholastic, 2017)

The figural test was implemented for this research to measure creativity levels amongst mechanical engineering undergraduates involved in generating product designs. The following creativity abilities are measured using the Figural test in TTCT. (Scholastic, 2017):

1. Fluency: Capability of the respondent in producing large numbers of figural images that reflect applicable ideas;

2. Originality: Capability of respondents to produce distinctive or 'unusual' responses in figural images drawn;

3. Elaboration: Capability of the respondents to embellish and further elaborate on ideas, focusing on attention to details; 
4. Abstractness of Title: Capability of the respondent to integrate and have a structured thought process, capturing vital information, to be able to segregate important points based on the perception of creativity that entails abstraction of thoughts, and

5. Resistance to Premature Closure: The tendency of a respondent to "stay open" while completing the open figures in the TTCT Forms to ensure enough time can open minds to different ideas, making generating original ideas possible.

Apart from these Figural Creativity abilities, this research defines the Overall Figural Creativity as the total scores of all Figural Creativity abilities.

\subsection{Creative Thinking Skills Module (CTSM)}

A new module named Creative Thinking Skills for Conceptual Engineering Design (CTSM) dedicated for Mechanical Engineering (ME) undergraduates was developed to stimulate and enhance creativity amongst ME undergraduates. This module also aims to ensure ME graduates are industry read. Six individual creative thinking skills are incorporated into this module.

\subsubsection{Attribute Listing}

Attribute listing could be utilized to improve product or systems as it aids users in producing new, creative solutions (Hassan, 2004). Problems or situations are broken down into smaller portions which are key attributes while performing attribute listing. Improvements or any feasible substitutes for each key attribute is then managed individually.

\subsubsection{Brain Sketching}

Alex Osborn's traditional brainstorming technique led to the development of brain sketching. Individuals involved will be in their respective teams and will silently sketch all ideas on a sheet of paper. No verbal discussing or writing out words representing ideas is allowed while performing brain sketching. Sketches will then be exchanged among team members and individuals will proceed to another round of sketching using the same sheet of paper containing the sketch by their team members. This process is repeated until everyone in the team has sketched on each other's sketches. (Linsey, et al., 2011). A sketch is different from a drawing as a sketch can be a quick, messy drawing to illustrate ideas (Lugt, 2002). Users can express themselves more effective as expressing ideas using a single picture is more effective as compared to verbal or written communication, hence the old saying "a picture speaks a thousand words". Students involved in product design has been proven to produce more ideas while utilizing the brain sketching method as compared to brainstorming (Lugt, 2002).

\subsubsection{Mind Mapping}

Mind mapping is an idea generation technique introduced by Tony Buzan (Buzann \& Buzan, 1996) which is proven to be effective amongst users and has been introduced to mechanical engineering undergraduates to enhance creativity. (Johari, et al., 18). Mind Map utilizes graphics to represent much useful information allows users to form connections between information and real-time scenario, stimulating users to generate improved and fresh ideas (Selvi \& G. Chandramohan, 2018). All information such as ideas and notes are organized into a tree branch-like structure in a mind map.

\subsubsection{Functional Decomposition}

In functional decomposition, users are not restricted to only considering physical components or parts as of performing physical decomposition but are encouraged to provide any ideas that could be a solution to achieve the required function. According to Ullman, there are four phases in performing functional decomposition namely recognizing the general function of a product required, generating subfunction descriptions, arranging subfunctions into a logical order and lastly enhancing subfunctions (Ullman, 2010). Research has suggested that functional decomposition could aid in improving creativity among users (Litchfield, Fan, \& Brown, 2011)

\subsubsection{Morphological Analysis}

The morphological analysis uses a table called a morphological chart or morphological diagram that is presented in table form containing functions and possible solutions for each function (Smith, Richardson, Summers, \& Mocko, 2012). Before constructing a morphological chart, problems are decomposed, and all vital functions required to tackle the problem is listed out in a column. Rows of the morphological chart are then filled up with possible functions that could tackle the stated problem. After all, functions have been addressed, possible combinations are formed to generate various theoretical solutions. This method enables users to list out all ideas systematically in table 
form for easy viewing and combination of ideas could be generated.

\subsubsection{SCAMPER}

SCAMPER is an acronym developed by De Bono consisting seven thinking processes namely substitute, combine, adapt, modify, put to other uses, eliminate and reverse roles (Barak, 2004) (Ozyaprak, 2015). New ideas could be developed from existing products using the SCAMPER method, this means existing products that require improvement, innovation or solve problems can utilize technique to generate new solutions. Research has shown that SCAMPER can stimulate creative thinking for users (Ozyaprak, 2015).

All six creative thinking skills incorporated in this module promotes divergent thinking that promotes one to provide a 'free flow' of ideas to come out with a solution, thus generating many possible solutions in the process.

\section{Research Methodology}

\subsection{Research Aims}

The research is conducted to answer a research question on how effective is the Creative Thinking Skills in improving the Figureal Creativity Ability of the Engineering undergraduates in specific Mechanical Engineering Undergraduates. The purpose of this study is to examine the effectiveness of the Creative Thinking Skills for Conceptual Engineering Design Module (CTSM) that was developed by the researcher on the Figural Creativity of Mechanical Engineering Undergraduates in a private institution of Higher Learning in Malaysia.

\subsection{Research Design}

Pre-Test and Post-Test can be utilized before and after the intervention, sessions to gauge the students' improvement in Creativity level especially in Figural Creativity ability and to understand and provide necessary assistance to enhance students' capability.

Various researchers applied Pre-test and Post-Test research design in establishing the impact of a various module as an intervention to improve students' achievement in various fields. In the language field, Obeidat and Alomari (2020) did a study on undergraduates' achievement in English Grammar, and Soo, K. Y and nor Haniza, H. (2014) determined the effect of learning styles for English subject. In the arts field, Altun and Atasoy (2019) did a study with regards to the effect of local dancers on teachers' attitude towards folk dance courses. In the mathematics field, Yusop et al. (2015) investigated the outcome of Mathematics Excellence Camp on repeat students for Pre-Calculus subject in Universiti Teknologi Mara (UiTM), Malaysia and De Cordova et al. (2005) investigate the lack of knowledge in basic Mathematical competence for students taking Math 2 and Math 3 courses in UCSC in Fall 2003. In the nursing field, Mekkawi et al. (2020) studied the effects of preparing nursing students for licensure examinations using remediation programs.

As the scores for Pre-Test and Post-Test were collected from the same students from the intervention group, the Paired Sample T-Test for Means by default is the best choice to be used to test the significant difference for Pre-Test and Post-Test marks. However, it must not be assumed that the data for the difference between Pre-Test and Post-Test for all Figural creativity ability is with approximately normal distribution, therefore a normality test must be performed first. To determine the normality of data, Shapiro-Wilk's test is preferred as the number of samples is small. After determining the distribution of the data, Paired Sample T-Test is applied for data with normal distribution, whereas, Wilcoxon Signed-Rank Test is applied for data that are not normally distributed. In order to answer the research question mentioned, a series of null hypotheses are established in regards to the experimental setup.

The null hypotheses for the study are:

$\mathrm{H}_{01}$ : There is no significant difference in pre and post-score in Fluency

$\mathrm{H}_{02}$ : There is no significant difference in pre and post-score in Originality

$\mathrm{H}_{03}$ : There is no significant difference in pre and post-score in Elaboration

$\mathrm{H}_{04}$ : There is no significant difference in pre and post-score in Abstractness of Title

$\mathrm{H}_{05}$ : There is no significant difference in pre and post-score in Resistance to Premature Closure

$\mathrm{H}_{06}$ : There is no significant difference in pre and post-score in Overall Figural Creativity

\subsection{Research Samples}

A purposive sampling method was applied in replacement of random sampling method in the selection and placement of subjects into the control and intervention groups. Prior approval was obtained from the Mechanical 
Engineering Department of the studied university to conduct the research. The respondents chosen for this research are $3^{\text {rd }}$-year Mechanical Engineering students undertaking a design module in the studied university.

A total of 62 students, who volunterered for the research, where 30 students from the Control group, while another 32 students form the Intervention Group. Experimental studies were conducted using Pre-Test and Post-Test designs as illustrated by Chua (2016) to treatment groups and control groups such as descriptions in Table 1 below:

Table 1. Pre-Test and Post-Test Design

\begin{tabular}{cccc}
\hline Type of Group & Pre-Test Measurement & Intervention & Post-Test Measurement \\
\hline Control Group & M1 & & M3 \\
Intervention Group & M2 & X & M4 \\
\hline
\end{tabular}

Keys:

$\mathrm{X}$ - Intervention using CTSM

$\mathrm{M}$ - Measurements

\section{Results}

\subsection{Normality Test Results}

Normality test is performed before determining the method of obtaining results of the null hypothesis for this research.

According to previous researchers, Shapiro Wilk's test with ( $\mathrm{p}>$.05) (Shapiro \& Wilk, 1965; Razali \& Wah, 2011), complemented with a visual inspection of the histogram, normal Q-Q plot, and box plot could provide sufficient support to determine the distribution pattern of Pre- Test and Post- Test scores to be approximately normally distributed.

The results of the Shapiro Wilk's test are shown in the Table 2 below:

Table 2. Tests of Normality Results

\begin{tabular}{lcccccc}
\hline & \multicolumn{3}{c}{ Kolmogorov-Smirnov $^{\text {a }}$} & \multicolumn{3}{c}{ Shapiro-Wilk } \\
& Statistic & df & Sig. & Statistic & df & Sig. \\
\hline Difference_FL & .145 & 32 & .085 & .956 & 32 & .207 \\
Difference_OR & .192 & 32 & .004 & .901 & 32 & .007 \\
Diffeerence_EL & .206 & 32 & .001 & .921 & 32 & .023 \\
Difference_AB & .191 & 32 & .004 & .803 & 32 & .000 \\
Difference_CL & .101 & 32 & $.200^{*}$ & .983 & 32 & .882 \\
Difference_OV & .094 & 32 & $.200^{*}$ & .954 & 32 & .192 \\
\hline
\end{tabular}

*. This is a lower bound of the true significance.

a. Lilliefors Significance Correction

A summary of overall normality test results is provided in Table 3 below: 
Table 3. Summary of Overall Normality Test Results

\begin{tabular}{cc}
\hline Test Method & Shapiro Wilk's Test \\
\hline Sample & $\mathrm{p}=.207$ \\
$(\mathrm{p}>.05)$ \\
Figural Fluency & $\mathrm{p}=.007$ \\
& $(\mathrm{p}<.05)$ \\
Figural Originality & $\mathrm{p}=.023$ \\
Figural Elaboration & $(\mathrm{p}<.05)$ \\
& $\mathrm{p}=.000$ \\
Figural Abstractness of Title & $(\mathrm{p}<.05)$ \\
& $\mathrm{p}=.882$ \\
Figural Resistance to Premature Closure & $(\mathrm{p}>.05)$ \\
Figural Overall Creativity & $\mathrm{p}=.192$ \\
& $(\mathrm{p}>.05)$
\end{tabular}

The overall results for the Test of Normality are shown in Table 3. Clearly, for $\mathrm{p}>.05$, Paired-sample T-Test will be applied to test the $\mathrm{H}_{01}, \mathrm{H}_{05}$ and $\mathrm{H}_{06}$. For $\mathrm{H}_{02}, \mathrm{H}_{03}$, and $\mathrm{H}_{04}$, Wilcoxon Signed-Rank Test will be applied. This is illustrated in Table 4.

Table 4. Null Hypothesis and Respective Method

\begin{tabular}{ccc}
\hline No & Null Hypothesis & Method \\
\hline 1 & $\begin{array}{c}\text { There is no significant difference in pre and post-mark in Fluency } \\
\text { There is no significant difference in pre and post-mark in } \\
\text { Originality }\end{array}$ & $\begin{array}{c}\text { Paired Sample T-Test } \\
\text { Wilcoxon Signed Rank Test }\end{array}$ \\
3 & $\begin{array}{c}\text { There is no significant difference in pre and post-mark in } \\
\text { Elaboration }\end{array}$ & Wilcoxon Signed Rank Test \\
4 & There is no significant difference in pre and post-mark in & Abstractness of Title \\
5 & There is no significant difference in pre and post-mark in & Wilcoxon Signed Rank Test \\
& Resistance to Premature Closure & Paired Sample T-Test
\end{tabular}

\subsection{Figural Creativity: Fluency}

Table 5 shows that the TTCT test scores for Pre-Test and Post-Test for Figural Fluency, and there was a significant difference between the scores of the two tests ( $\mathrm{Stat}=4.4048, \mathrm{p}<0.05), \mathrm{H}_{01}$ is rejected. Therefore, the results suggest that students' Fluency ability significantly improved after the delivery of the intervention programme.

Table 5. T-Test: Paired Two Sample for Means of Fluency

\begin{tabular}{ccc}
\hline & Pre-Test & Post-Test \\
\hline Mean & 19.4375 & 28.0625 \\
Observation & 32 & 32 \\
Pearson Correlation & 0.5467 & \\
t-Stat & -4.4048 & \\
$\mathrm{P}(\mathrm{T}<=\mathrm{t})$ two-tail & 0.0001172 & \\
$\mathrm{t}$ Critical two-tail & 2.0395 & \\
\hline
\end{tabular}




\subsection{Figural Creativity: Originality}

Table 6 illustrates the results of the Wilcoxon Signed-Rank Test for the Figural Originality. The results indicated 18 respondents did show improvement after the intervention, 8 respondents shown a reduction in the ability after the intervention while 6 respondents show no changes in the ability. Significance $p$-value at 2-tailed is at $p<.05$, thus $\mathrm{H}_{02}$ is rejected. The results indicated that there is a significant difference in the Pre-Test and Pot-Test scores for Figural Originality ability. The results also suggest that there is a significant improvement in the Figural Originality ability of respondents.

Table 6. Wilcoxon Signed Rank Test for Figural Originality

\begin{tabular}{ccccc}
\hline & Ranks & & & \\
& & $\mathrm{N}$ & Mean Rank & Sum of Ranks \\
\hline & Negative Ranks & $8^{\mathrm{a}}$ & 9.38 & 75.00 \\
Originality Post Test Score - & Positive Ranks & $18^{\mathrm{b}}$ & 15.33 & 276.00 \\
Originality Pre Test Scores & Ties & $6^{\mathrm{c}}$ & & \\
& Total & 32 & & \\
\hline
\end{tabular}

a. Originality Post Test Scores < Originality Pre Test Scores

b. Originality Post Test Scores > Originality Pre Test Scores

c. Originality Post Test Scores $=$ Originality Pre Test Scores

\begin{tabular}{ll}
\hline Test Statisticsa & $\begin{array}{l}\text { Originality Post Test Score } \\
\text { Originality Pre Test Scores }\end{array}$ \\
\hline $\mathrm{Z}$ & $-2.562 \mathrm{~b}$ \\
Asymp. Sig. (2-tailed) & .010 \\
\hline
\end{tabular}

a. Wilcoxon Signed Ranks Test

b. Based on negative ranks.

\subsection{Figural Creativity: Elaboration}

Table 7 illustrates the results of the Wilcoxon Signed-Rank Test for the Figural Elaboration. The results indicated 27 respondents did show improvement after the intervention, 2 respondents shown a reduction in the ability after the intervention while 3 respondents show no changes in the ability. The significance value of $p$ is at 2 -tailed is at $p<.05$, hence $\mathrm{H}_{03}$ is rejected. The results indicated that there is a significant difference in the Pre-Test and Pot-Test scores for Figural Elaboration ability. The results also suggest that there is a significant improvement in the Figural Elaboration ability of respondents.

Table 7. Wilcoxon Signed Rank Test for Figural Elaboration

\begin{tabular}{lllll}
\hline Ranks & & & \\
& & $\mathrm{N}$ & Mean Rank & Sum of Ranks \\
\hline \multirow{2}{*}{$\begin{array}{l}\text { Elaboration Post } \\
\text { Elaboration Pre Test Scores Scores }\end{array}$} & Negative Ranks & $2^{\mathrm{a}}$ & 8.00 & 16.00 \\
\multicolumn{2}{l}{-Positive Ranks } & $27^{\mathrm{b}}$ & 15.52 & 419.00 \\
& Ties & $3^{\mathrm{c}}$ & & \\
\hline
\end{tabular}

a. Elaboration Post Test Scores < Elaboration Pre Test Scores

b. Elaboration Post Test Scores > Elaboration Pre Test Scores

c. Elaboration Post Test Scores $=$ Elaboration Pre Test Scores

\begin{tabular}{ll}
\hline Test Statistics $^{\mathrm{a}}$ & $\begin{array}{l}\text { Elaboration Post Test Scores } \\
\text { Elaboration Pre Test Scores }\end{array}$ \\
\hline $\mathrm{Z}$ & $-4.447^{\mathrm{b}}$ \\
Asymp. Sig. (2-tailed) & .000 \\
\hline
\end{tabular}

a. Wilcoxon Signed Ranks Test

b. Based on negative ranks. 


\subsection{Figural Creativity: Abstractness of Title}

Table 8 illustrates the results of the Wilcoxon Signed-Rank Test for the Figural Abstractness of Title. The results indicated 10 respondents did show improvement after the intervention, 16 respondents shown a reduction in the ability after the intervention while 6 respondents show no changes in the ability. The significance value of $p$ is at 2-tailed is at $\mathrm{p}>.05$, hence $\mathrm{H}_{04}$ is accepted. The results indicated that there is no significant difference in the Pre-Test and Pot-Test scores for Figural Abstractness of Title ability. The results also suggest that there is no significant improvement in the Figural Abstractness of Title ability of respondents.

Table 8. Wilcoxon Signed Rank Test for Figural Abstractness of Title

\begin{tabular}{|c|c|c|c|c|}
\hline \multicolumn{5}{|l|}{ Ranks } \\
\hline & & $\mathrm{N}$ & Mean Rank & Sum of Ranks \\
\hline \multirow{4}{*}{$\begin{array}{l}\text { Abstractness Post Test Scores } \\
\text { Abstractness Pre Test Scores }\end{array}$} & Negative Ranks & $16^{\mathrm{a}}$ & 12.66 & 202.50 \\
\hline & _Positive Ranks & $10^{\mathrm{b}}$ & 14.85 & 148.50 \\
\hline & Ties & $6^{c}$ & & \\
\hline & Total & 32 & & \\
\hline
\end{tabular}

a. Abstractness Post Test Scores < Abstractness Pre Test Scores

b. Abstractness Post Test Scores > Abstractness Pre Test Scores

c. Abstractness Post Test Scores $=$ Abstractness Pre Test Scores

\begin{tabular}{ll}
\hline Test Statistics $^{\mathrm{a}}$ & \\
& $\begin{array}{l}\text { Abstractness Post Test Scores - } \\
\text { Abstractness Pre Test Scores }\end{array}$ \\
\hline $\mathrm{Z}$ & $-.689^{\mathrm{b}}$ \\
Asymp. Sig. (2-tailed) & .491 \\
\hline
\end{tabular}

a. Wilcoxon Signed Ranks Test

b. Based on positive ranks.

\subsection{Figural Creativity: Resistance to Premature Closure}

Table 9 shows that the TTCT test scores for Pre-Test and Post-Test for Figural Resistance to Premature Closure, and there is a significant difference between the scores of the two tests ( $\mathrm{t}$ Stat $=2.1460, \mathrm{p}<0.05$ ), thus, $\mathrm{H}_{05}$ is rejected. Therefore, the results suggest that students' Resistance to Premature Closure ability significantly improved after the delivery of the intervention programme.

Table 9. T-Test: Paired Two Sample for Means of Premature Closure

\begin{tabular}{ccc}
\hline & Pre-Test & Post-Test \\
\hline Mean & 13.3438 & 15.25 \\
Observation & 32 & 32 \\
Pearson Correlation & -0.0047 & \\
t-Stat & 2.1460 & \\
$\mathrm{P}(\mathrm{T}<=\mathrm{t})$ two-tail & 0.0398 & \\
t Critical two-tail & 2.0395 & \\
\hline
\end{tabular}

\subsection{Overall Figural Creativity}

Table 10 shows that the TTCT test scores for Pre-Test and Post-Test for Overall Figural Creativity and there was a significant difference between the scores of the two tests ( $\mathrm{Stat}=4.7145, \mathrm{p}<0.05$ ), thus, $\mathrm{H}_{06}$ is rejected. Therefore, the results suggest that students' Overall Figural Creativity significantly improved after the delivery of the intervention programme. 
Table 10. T-Test: Paired Two Sample for Means for Overall Figural Creativity

\begin{tabular}{ccc}
\hline & Pre-Test & Post-Test \\
\hline Mean & 52.3438 & 67 \\
Observation & 32 & 32 \\
Pearson Correlation & 0.5749 & \\
t-Stat & -4.7145 & \\
$\mathrm{P}(\mathrm{T}<=\mathrm{t})$ two-tail & $4.8611 \mathrm{E}-5$ & \\
t Critical two-tail & 2.0395 & \\
\hline
\end{tabular}

\subsection{Summary of Results}

The results of this study illustrated that 4 out of 5 Figural creativity abilities have significant improvement after implementation of the Creative Thinking Skills Module (CTSM) developed by the researcher. Overall creativity performance of students also increased significantly after the delivery of the module. Statistical tests displayed a significant difference between the scores of the two TTCT Figural Forms assessment. The current study findings support the need for the implementation of teaching creativity in engineering design to improve the creativity level of undergraduates.

\section{Conclusion}

A Creative Thinking Skills Module (CTSM) was developed to address the decline in the creativity of undergraduates. A group of $3^{\text {rd }}$ year ME undergraduate attended and completed the CTSM workshop. Their Figural Creativity before and after the workshop was assessed using TTCT Figural Form A for Pre-Test and Form B for Post-Test. Two different methods were applied, that is the Paired Sample T-Test and the Wilcoxon Signed Rank Test to study the difference in the scores.

The major findings of the study are that the CTSM had significantly improved of 4 Figural Creativity abilities, namely Fluency, Originality, Elaboration and Resistance to Premature Closure. The CTSM, however, failed to improve the ability of the students to capture vital information, integrate and have the structured thought process to come up with abstract perception towards product design, namely the Abstractness of Title ability. Based on the findings above, it can be concluded that Engineering undergraduate students can be trained or educated to be more creative when comes to deriving various relevant design of products or solutions.

The results obtained in this study is related to Engineering Design, where creativity is required. The research doesn't look into the assessment of the Creativity of the Product Design, which is the manidestation of the creative ability after acquiring the relevant skills.

Until this point in time, there are as yet restricted number of literature available in the review, effectiveness and suggestions towards the inclusion of creative thinking elements in the conduct of courses. Actually, the elements of creative thinking have been playing a minor commitment towards the satisfaction of the standards, as opposed to being featured in the engineering programs as a sole module to be actualized in the designing project. Hence, with the polularisation of the creative thinking module in the engineering programme, more improvements and comparison of the results will be able to be sought.

With the implementation of the creative thinking module in the engineering programme, the Institution of Higher Learning may also want to consider revisiting and relooking at some of the potential hold-back factors. These include the lack of lecturers who are fluent in the subject area, excessive study load on students, the learning and assessment of the module may be extrinsic, or students focuses the importance of creativity in the non-academic context.

Nevertheless, the importance of creativity in engineering programmes will still need to be highlighted as engineers also contribute to the creation of the world through the application of the knowledge of science, and in this sense, creativity is important to differentiate one design from others in a more holistic way.

\section{References}

Altun M., \& Atasoy M. (2019). The Effect of Various Local Dances on Prospective Physical Education Teachers' Attitudes towards the Folk-Dance Course. International Journal of Higher Education, 8(1), 19-22. https://doi.org/10.5430/ijhe.v8n1p19

Amabile, T. (1989). Growing Up Creative: Nurturing a lifetime of creativity. New York: Springer-Verlag. 
Baillie, C. (2002). Enhancing creativity in engineering students. Engineering Science and Education Journal, 185-192. https://doi.org/10.1049/esej:20020503

Barak, M. (2004). Systematic Approaches for Inventive Thinking and Problem-Solving: Implications for Engineering Education. International Journal of Engineering Education, 612-618.

Beghetto, R. A. (2010). Creativity in the Classroom. In J. C. Kaufman, \& R. J. Sternberg, The Cambridge handbook of Creativity, 447-463. https://doi.org/10.1017/CBO9780511763205

Brand, G., Hendy, L., \& Harrison, R. (2015). Mining the Gap! Fostering Creativity and Innovative Thinking. The International Design Technology Conference, DesTech 2015, 79-84. Geelong Australia: Procedia Technology. https://doi.org/10.1016/j.protcy.2015.07.014

Buzann, T., \& Buzan, B. (1996). The Mind Map Book. New York: Penguin Books.

Claxton, C., Edwards, L., \& Scale-Constantinou, V. (2006). Cultivating Creative Mentalities: A framework for education. In Thinking Skills and Creativity 1, 57-61. https://doi.org/10.1016/j.tsc.2005.11.001

Cropley, A. (2001). Creativity in Education and Learning: A guide to Teachers and Educators. London: Kogan. https://doi.org/10.5860/CHOICE.39-4104

Cropley, D. (2015). The importance of Creativity in Engineering. In D. Cropley, Creativity in Engineering, 13-54. Sydney: Academic Press. https://doi.org/10.1016/B978-0-12-800225-4.00002-1

Daly, S., Mosyjowski, E., \& Seifert, C. M. (2014). Teaching Creativity in Engineering Courses. Journal of Engineering Education, 417-449. https://doi.org/10.1002/jee.20048

Daud, A. M., Omar, J., Turiman, P., \& Osman, K. (2012). Creativity in Science Education. UKM Teaching and Learning Congress 2011, 467-474. Procedia Social and Behavioral Science. https://doi.org/10.1016/j.sbspro.2012.09.302

De Cordova, H.G., Alvarado, G., Herzon, C., Bäuerle, F., Migliore, E., \& Tappero, S. (2005). Increasing Students' Mathematical Competence by Developing an Interactive Instructional Context for Math 2 and Math 3. Final Report University of California at Santa Cruz

Engineering Accreditation Council. (2017). EAC 2017 Manual. Board of Engineers Malaysia.

Grapragasem, S., Krishnan, A., \& Mansor, A. N. (2014). Current Trends in Malaysian Higher Education and the Effect on Education Policy and Practice: An Overview. International Journal of Higher Education, 85-93. https://doi.org/10.5430/ijhe.v3n1p85

H. Yusop., F.Y. Foo, Jumadi A., S. Mahadi., M. N. Ali., \& N. Johari. (2015). The Effectiveness of Excellence Camp: A Study on Paired Sample. Procedia Economics and Finance 31, 453-461. https://doi.org/10.1016/S2212-5671(15)01174-0

Haertel, T., Terkowsky, C., \& Jahnke, I. (2012). Where have all the inventors gone? Is There a Lack of spirit of research in engineering education curricula? 15th International Conference on Interactive Collaborative Learning and 41 st International Conference on Engineering Pedagogy in Villach. Vienna. https://doi.org/10.1109/ICL.2012.6402085

Hassan, H. (2004). Creativity and Innovation for Electrical and Computer Engineering Research. American Society for Engineering Education Annual Conference \& Exposition.

Hewett, T. T. (2005). Informing the design of computer-based environments to support creativity. International Journal of Human-Computer Studies, 383-409. https://doi.org/10.1016/j.ijhcs.2005.04.004

Johari, J., Sahari, D. A., Abdullah, S., Ramli, R., Yassin, R. M., \& Muhamad, N. (18). Systematic Infusion of Creativity in Engineering Design Courses. Procedia Social and Behavioral Sciences, 255-259. Elsevier. https://doi.org/10.1016/j.sbspro.2011.05.036

Kazerounian, K., \& Foley, S. (2007). Barriers to Creativity in Engineering Education: A Study of Instructors and Students Perception. Journal of Mechanical Design, 761-768. https://doi.org/10.1115/1.2739569

Kim, K. H. (2006). Can We Trust Creativity Tests? A Review of the Torrance Tests of Creative Thinking (TTCT). Creativity Research Journal, 3-14. https://doi.org/10.1207/s15326934crj1801_2

Linsey, J. S., Clauss, E. F., Kurtoglu, T., Murphy, J. T., Wood, K. L., \& Markman, A. B. (2011). An Experimental Study of Group Idea Generation Techniques: Understanding the Roles of Idea Representation and Viewing 
Methods. Journal of Mechanical Engineering. https://doi.org/10.1115/1.4003498

Litchfield, R. C., Fan, J., \& Brown, V. R. (2011). Directing idea generation using brainstorming with specific novelty goals. Motivation and Emotion, Springer Science + Business Model. https://doi.org/10.1007/s11031-011-9203-3

Liu, Z. C., \& Schönwetter, D. K. (2004). Teaching Creativity in Engineering Education. International Journal of Engineering Education, 801-808.

Lugt, R. v. (2002). Brainsketching and How It Differs from Brainstorming. Creativity and Innovation Management, 43-54. https://doi.org/10.1111/1467-8691.00235

Ozyaprak, M. (2015). The Effectiveness of SCAMPER Technique on Creative Thinking Skills. Journal for the Education of Gifted Young, 31-40. https://doi.org/10.17478/JEGYS.2016116348

Mekkawi A.M., Qatouni F., Alhalalmeh S., Maalouf I., Daradkeh F., \& Fattah H. A. (2020). The Effect of Remediation Program in Preparing Nursing Students for Licensure Examination. International Journal of Higher Education, 9(3), 49-54. https://doi.org/10.5430/ijhe.v9n3p49

N. M. Razali, \& Y. B. Wah. (2011). Power comparisons of Shapiro-Wilk, Kolmogorov-Smirnov, Lilliefors and Anderson-Darling tests. Journal of Statistical Modeling and Analytics, 2(1), 21-33.

Obeidat M. M., \& Alomari. M. A. (2020). The Effect of Inductive and Deductive Teaching on EFL Undergraduates' Achievement in Grammar at the Hashemite University in Jordan. International Journal of Higher Education, 9(2), 280-288. https://doi.org/10.5430/ijhe.v9n2p280

Rhodes, M. (1961). An Analysis of Creativity. In The Phi Delta Kappan, 302-310. Phi Delta Kappa International.

Robinson, S. K. (2013). Out of our minds. John Wiley. https://doi.org/10.1002/9780857086549

Shapiro, S.S., \& Wilk, M.B. (1965). An Analysis of Variance Test for Normality (Complete Samples). Biometrika, 52(3/4), 591-611. https://doi.org/10.1093/biomet/52.3-4.591

Scholastic. (2017). Streamlined Scoring Guide. Scholastic Testing Services.

Scholastic. (2018). The Torrance ${ }^{\circledR}$ Tests of Creative Thinking and Gifted Education Products at STS. Retrieved from Scholastic Testing Service: https://www.ststesting.com/gift/

Selvi, R., \& G. Chandramohan. (2018). Case Study on Effective use of Mind map in Engineering Education. IEEE Ninth International Conference on Technology for Education (T4E), 205-207. IEEE Computer Society. https://doi.org/10.1109/T4E.2018.00053

Smith, G., Richardson, J., Summers, J. D., \& Mocko, G. M. (2012). Concept Exploration Through Morphological Charts: An Experimental Study. Journal of Mechanical Design. https://doi.org/10.1115/1.4006261

Soon, T.-K., \& Quek, A.-H. (2013). Engineering education in Malaysia - Meeting the needs of a rapidly emerging economy and globalisation. International Conference on Interactive Collaborative Learning (ICL), 583-587. Kazan: IEEE. https://doi.org/10.1109/ICL.2013.6644659

Terkowsky, C., \& Haertel, T. (2013). Where have all the inventors gone? Fostering creativity in Engineering Education with remote lab learning environments. IEEE Global Engineering Education Conference (EDUCON), 345-351. Berlin Germany: IEEE. https://doi.org/10.1109/EduCon.2013.6530127

Torrance, E. P. (1974). Torrance Tests of Creative Thinking: Norms-Technical manual. Bensenville, IL: Scholastic Testing Services. https://doi.org/10.3102/00028312005002272

Ullman, D. G. (2010). 7.3 A Technique for Designing with Function. In The Mechanical Design Process, 181-189. New York: McGraw- Hill. 